\title{
Agronomic and Economic Interactions between Sidedressed Nitrogen and Potassium Fertilizations on 'Atlantic' Potato
}

\author{
Renato Yagi ${ }^{*}$ \\ https://orcid.org/0000-0002-1111-0040
}

\section{Nilceu Ricetti Xavier de Nazareno ${ }^{2}$}

https://orcid.org/0000-0003-2429-4974

\author{
Rogério Peres Soratto 3 \\ https://orcid.org/0000-0003-4662-126X
}

\begin{abstract}
${ }^{1}$ Rural Development Institute of Paraná (IDR-Paraná), Ponta Grossa, Paraná State, Brazil; " IDR-Paraná, Curitiba, Paraná, Brazil; ${ }^{3}$ São Paulo State University (UNESP), College of Agricultural Sciences and Center for Tropical Roots and Starches, Botucatu, São Paulo, Brazil.
\end{abstract}

Received: 2019.10.19; Accepted: 2020.07.29.

*Correspondence: ryagi@idr.pr.gov.br; Tel.: +55-42-3219 9700 (R.Y.)

\section{HIGHLIGHTS}

- $\mathrm{N}$ and $\mathrm{K}$ are the nutrients taken up in greatest amounts by potato crop.

- Reported $\mathrm{N} \times \mathrm{K}$ interaction at planting also exists in the sidedress fertilization.

- $\mathrm{N} \times \mathrm{K}$ interaction in the sidedress fertilization is classified as Liebig-synergism.

- Joint $\mathrm{N}$ and $\mathrm{K}$ application as sidedressing is more profitable than their application at planting.

\begin{abstract}
Nitrogen $(\mathrm{N})$ and potassium $(\mathrm{K})$ in potato crop planting synergistically increase tuber yield, but there are no studies on this interaction in sidedressing. In two experiments with 'Atlantic' potato combinations of four $\mathrm{N}$ rates $\left(0,50,100\right.$, and $\left.150 \mathrm{~kg} \mathrm{ha}^{-1}\right)$ with four $\mathrm{K}_{2} \mathrm{O}$ rates $\left(0,100,200\right.$, and $\left.300 \mathrm{~kg} \mathrm{ha}^{-1}\right)$ were applied in sidedressing in a $4 \times 4$ factorial scheme with three replications in a completely randomized design. Adjacent commercial fields were sampled to economic comparisons with experimental results. Significant interaction between $\mathrm{N}$ and $\mathrm{K}$ sidedressing rates with tuber yields increase also was confirmed and classified as Liebigsynergism. Compared to the isolated $\mathrm{N}$ and $\mathrm{K}$ applications in sidedressing, joint $\mathrm{N}$ and $\mathrm{K}$ fertilizations, respectively, increases by $11 \%$ and $48 \%$ marketable tuber yields in the summer-fall experiment, and $12 \%$ and $7 \%$ in the spring experiment. Joint $\mathrm{N}$ and $\mathrm{K}$ applications as sidedressing was more profitable than planting fertilization, mainly at higher $\mathrm{N}$ and $\mathrm{K}$ rates. The response of specific gravity of 'Atlantic' potato tubers to the $\mathrm{N}$ and $\mathrm{K}$ sidedressing rates was mediated by interactions between edaphoclimatic conditions and inputs of $\mathrm{N}$ and $\mathrm{K}$. The combined application of $\mathrm{N}$ and $\mathrm{K}$ sidedressing rates increased specific gravity in the summerfall experiment, but had a negative effect in the spring experiment. Therefore, our results provide strong evidence that the fertilization management for potato crop in Brazil can be modified by applying higher amounts of $\mathrm{N}$ and $\mathrm{K}$ in sidedressing to match nutritional needs of the crop.
\end{abstract}

Keywords: Solanum tuberosum; mineral nutrition; synergistic effect. 
GRAPHICAL ABSTRACT

\section{N×K INTERACTIONS}
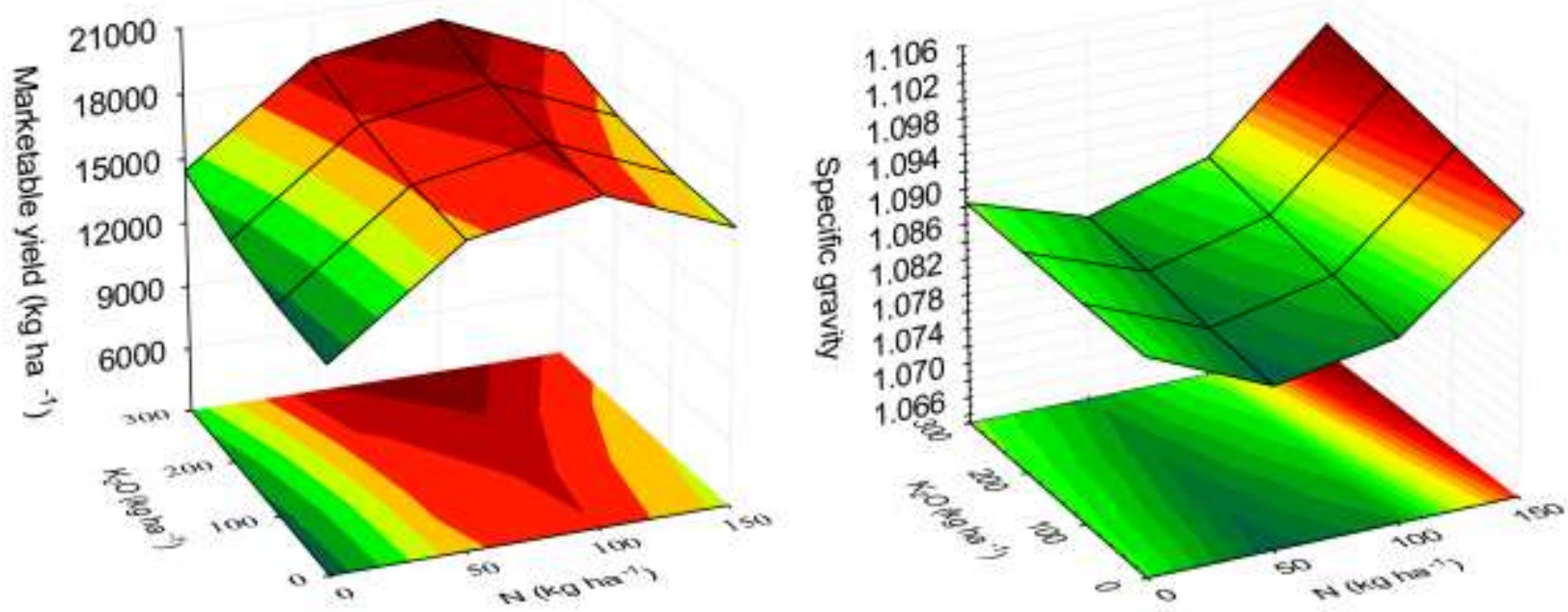

Summer-fall growing season
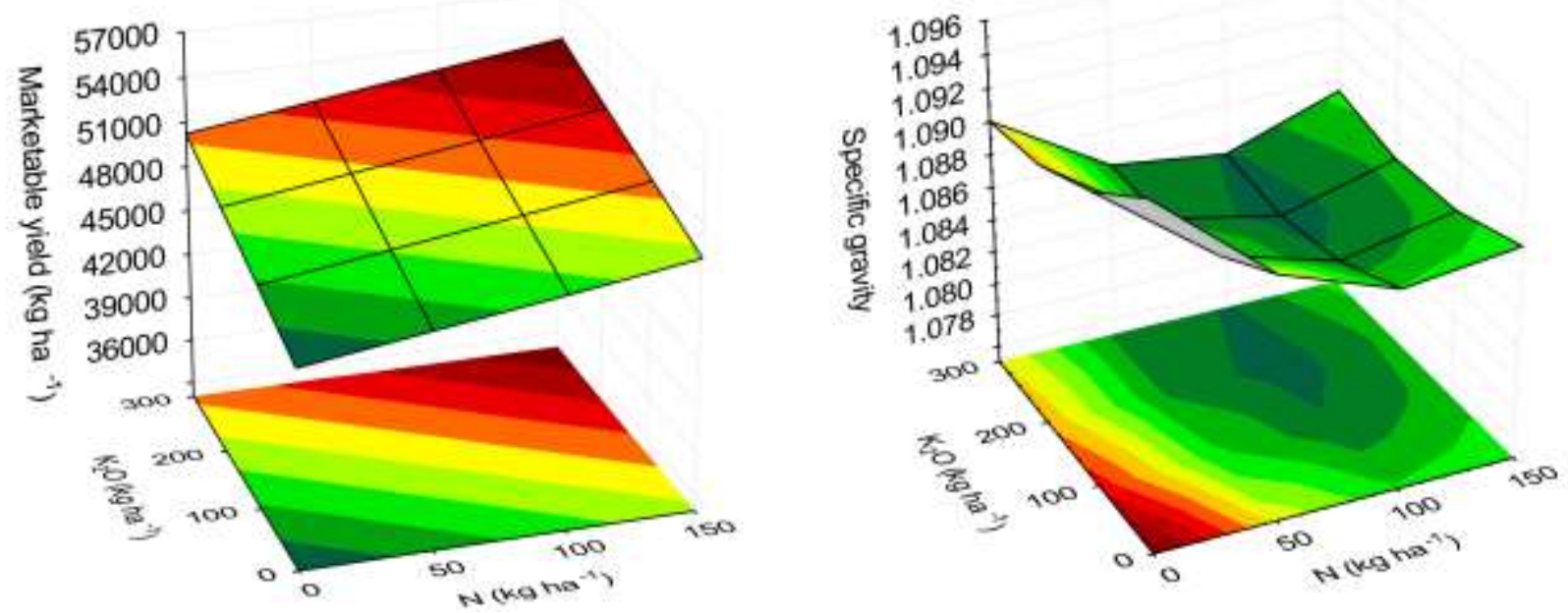

Spring growing season

\section{INTRODUCTION}

The $\mathrm{N}$ and $\mathrm{K}$ are the nutrients taken up in greatest amounts by potato (Solanum tuberosum $\mathrm{L}$.) plants [13] and suitable rates at planting synergistically increase potato yield [4-8]. However, unbalanced fertilization with $\mathrm{N}$ and $\mathrm{K}$ at planting can also reduce yield [6], specific gravity (SG) [4] or dry matter (DM) content of tubers, depending on potato genotype [9]. Excessive $\mathrm{N}$ and $\mathrm{K}$ applications reduce SG due to the increased water content of tubers to cell turgor maintenance against negative osmotic salt potential [6]. Tubers with higher water content absorb greater oil amounts during frying process due to heating and water evaporation [10], and high $\mathrm{N}$ and inadequate $\mathrm{K}$ supply increase acrylamide-forming potential in fried potatoes, a probable carcinogenic substance [11].

'Atlantic' potato, the most used cultivar for the chipping industry in Brazil, takes up $\mathrm{K}$ and $\mathrm{N}$ at maximum daily accumulation rates of 5.0 and $1.8 \mathrm{~kg} \mathrm{ha}^{-1} \mathrm{day}^{-1}$, respectively, during tuber bulking stage [2]. The dilution curves of $\mathrm{N}$ and $\mathrm{K}$ in the total $\mathrm{DM}$ of potato plants are proportional, indicating that the $\mathrm{N}$ concentration in plant tissues increases as $\mathrm{K}$ concentration increases and vice versa [12]. In potato plants, $\mathrm{N}$ is a primary component of nucleic acids, proteins and amino acids whereas $\mathrm{K}$ acts in the osmoregulation, in the activation of some enzyme systems, and in the translocation of carbohydrates [1]. Nitrogen $\times \mathrm{K}$ interaction depends on the form of $\mathrm{N}$ supply and levels of both nutrients, existing antagonism between ammonium $\left(\mathrm{NH}_{4}{ }^{+}\right)$and exchangeable $\mathrm{K}\left(\mathrm{K}^{+}\right)$due to similar charges and hydrated diameters, competing to the same binding sites of 
carriers [13]. Antagonistically, $\mathrm{NH}_{4}{ }^{+}$toxicity can be diminished by $\mathrm{K}$ uptake, while co-operative uptake, internal transport, and utilization occurs between $\mathrm{K}^{+}$and nitrate $\left(\mathrm{NO}_{3}^{-}\right)$[14]. On the other hand, the presence of chlorine $(\mathrm{Cl})$ and magnesium $(\mathrm{Mg})$ in the soil, respectively, increases $\mathrm{NO}_{3}{ }^{-}$and $\mathrm{K}^{+}$demands by potato plants, favoring synergistic effects of $\mathrm{N}$ and $\mathrm{K}$ on the tuber yields $[4,15]$. Both, $\mathrm{N}$ and $\mathrm{K}$ affect the $\mathrm{SG}$ of potato tubers with a synergistic effect between them, although the most pronounced effect is that of $N$ [4]. The addition of excessive amounts of $\mathrm{N}$ or $\mathrm{K}$, particularly as high salinity sources, like $\mathrm{KCl}$, reduces the solid content in potato tubers [16]. Joint applications of $\mathrm{N}$ and $\mathrm{K}$ increased the water demand to maintain the cell turgor pressure against increasing the negative potential of solutes, and thus having an additive effect on the reduction of tuber SG [6].

Nitrogen and $\mathrm{K}$ also interact in the soil. On one hand, presence of $\mathrm{N}$ may decrease $\mathrm{K}^{+}$leaching due to increase of plants uptake; on the other hand, $\mathrm{N}$ fertilization with urea may increase $\mathrm{K}^{+}$leaching due to its displacement to soil solution by $\mathrm{Ca}^{2+}$ and $\mathrm{Mg}^{2+}$ also displaced by protons produced with nitrification [13]. Fertilizer recommendations for the potato crop in Brazil indicate massive applications of $\mathrm{N}$ and $\mathrm{K}$ in the planting furrows, along with all $\mathrm{P}$ fertilizer, and $\mathrm{N}$ sidedressing before hilling [17-18]. Brazilian potato farmers traditionally have used high fertilizer rates at planting (e.g., 3-4 $\mathrm{Mg} \mathrm{ha}^{-1} 4-14-8 \mathrm{~N}-\mathrm{P}_{2} \mathrm{O}_{5}-\mathrm{K}_{2} \mathrm{O}$, regardless of soil fertility), to prevent lack of nutrients for the plants and consequent financial profitability drop [19]. This traditional fertilization practice is not in accordance to the initial nutritional demands of the 'Atlantic' potato cultivar, which takes up only $16 \% \mathrm{~N}$ and $20 \% \mathrm{~K}$ before tuber initiation [2]. Under in vitro conditions, increasing the availability of both nutrients increased microtuber number and decrease microtuber size [20], while the large and medium tuber yields were increased and small and very small sized tuber yields were decreased in field conditions [7]. Grade tuber weight increase with increase of both N and $\mathrm{K}$ rates at planting but decrease peeling losses, a very important character for chipping industry [6].

Thus, we hypothesized that: a) a certain combination of $\mathrm{N}$ and $\mathrm{K}$ sidedressing rates can increase yield and quality of 'Atlantic' potato tubers, and $\mathrm{b}$ ) rates of $\mathrm{N}$ and $\mathrm{K}$ similar to that traditionally used but distributed according to phases of nutritional requirements increase profitability. The objective of this study was to evaluate the effect of combined $\mathrm{N}$ and $\mathrm{K}$ rates as sidedressing on yield and quality of marketable tubers of 'Atlantic' potato grown in the summer-fall and spring growing seasons, as well as to compare economically similar $\mathrm{N}$ and $\mathrm{K}$ amounts in split application and in traditional full application at planting furrow.

\section{MATERIAL AND METHODS}

\section{Site characteristics}

Two field experiments were carried out in the summer-fall (January 16th to May 16th) and spring (September 08th to December 07th) growing seasons of 2013, in commercial areas of potato production. The experiments were performed, respectively, in a clayey Oxisol in Lapa (49² $43^{\prime} 8^{\prime \prime} \mathrm{W}, 2^{\circ} 46^{\prime} 15^{\prime \prime} \mathrm{S}, 942 \mathrm{~m}$

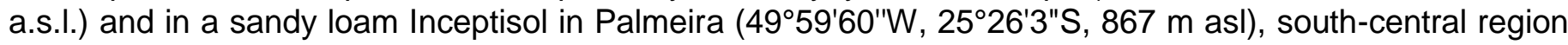
of Paraná State, southern Brazil. According to the Köppen classification system, the region has a Cfb climate. Weather conditions were monitored from weather stations in Lapa municipality (summer-fall growing season) and Ponta Grossa municipality (distant $40 \mathrm{~km}$ of the experimental area in the spring growing season), representing the regional climatic conditions for the experiments (Figure 1). Before initiating each experiment, the chemical [21] and textural [22] characteristics of the topsoil (0-0.20 m depth) were evaluated (Table 1). The soil was tilled with chiseling, plowing, and light harrowing on the day before planting. 


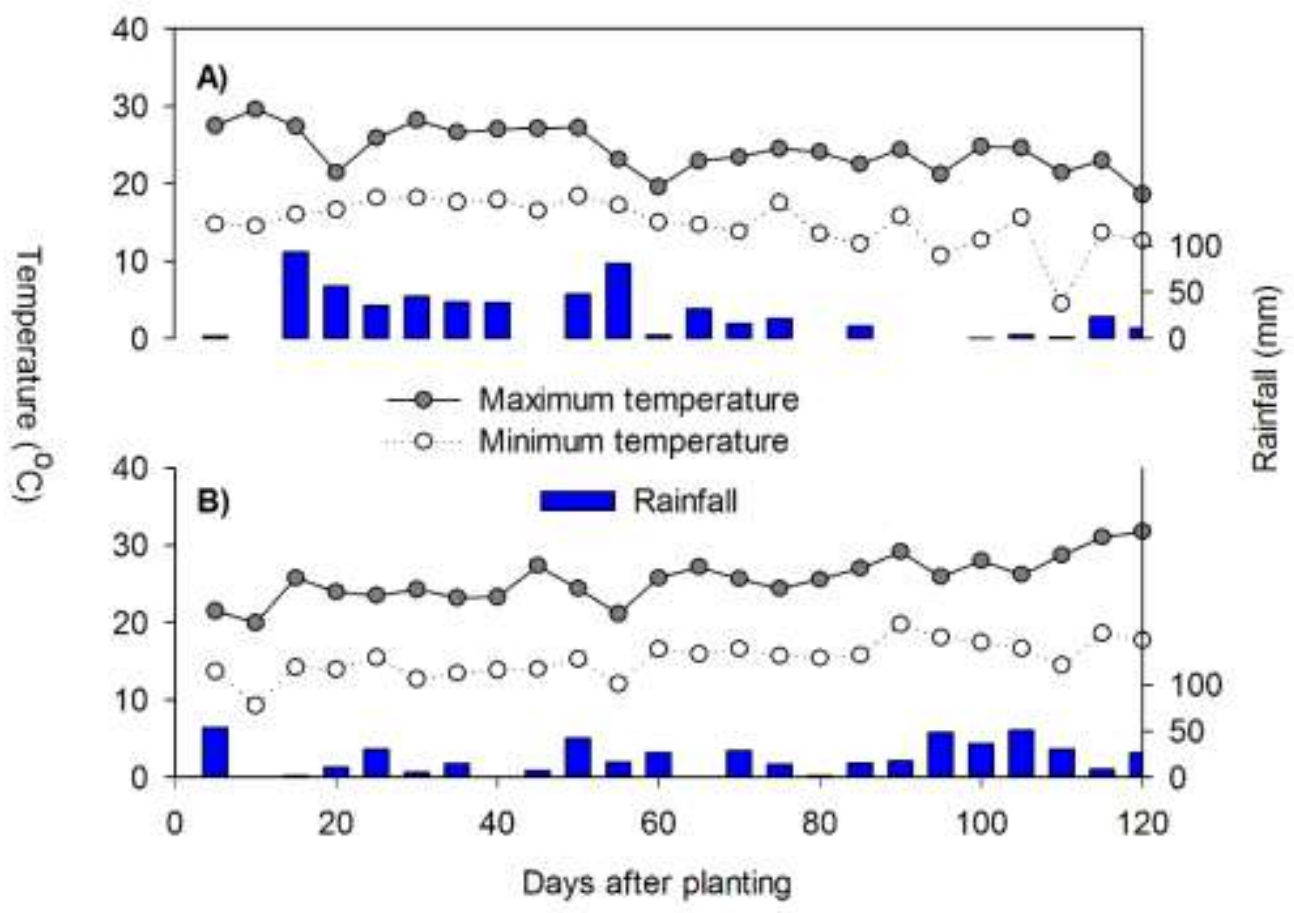

Figure 1. Maximum (grey circles) and minimum (white circles) temperature and rainfall (black bars) for each period of five days in the summer-fall $(A)$ and in the spring (B) growing seasons from planting to harvesting dates, during February to May 2013 and September to December 2013, respectively.

Table 1. Chemical and textural characteristics of the soils at the experimental sites before the potato planting.

\begin{tabular}{|c|c|c|c|c|c|c|c|c|c|}
\hline Growing season & $\mathrm{pH}^{\mathrm{a}}$ & $\mathrm{Pb}$ & $C^{c}$ & $\mathrm{Ca}^{\mathrm{d}}$ & $\mathrm{Mg}^{\mathrm{d}}$ & $K^{d}$ & $\mathrm{Ve}^{\mathrm{e}}$ & Clay & Sand \\
\hline & & $\mathrm{mg} \mathrm{dm}^{-3}$ & $\mathrm{~g} \mathrm{dm}^{-3}$ & & olc dm & & $\%$ & 5 & \\
\hline Summer-fall & 5.1 & 27.5 & 33.4 & 7.8 & 3.7 & 0.16 & 62 & 451 & 356 \\
\hline Spring & 5.1 & 42.2 & 18.6 & 5.8 & 1.2 & 0.26 & 63 & 244 & 642 \\
\hline
\end{tabular}

a1:2.5 soil/ $\mathrm{CaCl}_{2}$ suspension $0.01 \mathrm{~mol} \mathrm{~L}^{-1} \mathrm{CaCl}_{2}$ extractor; ${ }^{b}$ Mehlich-1 extractor; 'Walkley and Black method; ${ }^{\mathrm{d} K C l} 1 \mathrm{~mol}$ $\mathrm{L}^{-1}$ extractor; ${ }^{\mathrm{V}} \mathrm{V}$ is base saturation index.

\section{Crop management, treatments, and measurements}

Planting were mechanically carried out on 16 January 2013 in the summer-fall growing season and on 10 August 2013 in the spring growing season, with $0.80-\mathrm{m}$ spacing between furrows. Uncut type III seed tubers (approximately $35 \mathrm{~g}$ in mass) of cultivar Atlantic were hand planted with $0.35 \mathrm{~m}$ apart between seed tubers within rows. At planting, all plots received $1.4 \mathrm{Mg} \mathrm{ha}^{-1}$ of 6-30-6 NPK fertilizer $\left(84 \mathrm{~kg} \mathrm{ha}^{-1} \mathrm{~N}, 420 \mathrm{~kg}\right.$ ha $^{-1} \mathrm{P}_{2} \mathrm{O}_{5}$, and $84 \mathrm{~kg} \mathrm{ha}^{-1} \mathrm{~K}_{2} \mathrm{O}$ ) in both growing seasons. Phosphorus rate was based on the $\mathrm{P}_{2} \mathrm{O}_{5}$ rate traditionally used by Brazilian potato growers (420 kg ha-1 $\mathrm{P}_{2} \mathrm{O}_{5}$ in $3.0 \mathrm{Mg} \mathrm{ha}^{-1}$ of 4-14-8 NPK fertilizer). Thus, the $\mathrm{N}$ and $\mathrm{K}$ planting rates in this study were consistent with the potato crop recommendations in Paraná State, Brazil [18], but less than the traditionally fertilizer usage of $120-160 \mathrm{~kg} \mathrm{ha}^{-1} \mathrm{~N}$ and $240-320 \mathrm{~kg} \mathrm{ha}^{-1} \mathrm{~K}_{2} \mathrm{O}$ used by Brazilian potato growers [19].

Plots consisted of four 5.0-m-long rows, and the three central rows were considered for data collection; the $0.5 \mathrm{~m}$ at each end of each row and the two outer rows of the plot were considered borders. At 30 and 35 days after planting (DAP), respectively, in the summer-fall and spring seasons, a combination of four $\mathrm{N}$ rates $\left(0,50,100\right.$, and $150 \mathrm{~kg} \mathrm{ha}^{-1}$, as ammonium sulfate) and four $\mathrm{K}_{2} \mathrm{O}$ rates $\left(0,100,200\right.$, and $300 \mathrm{~kg} \mathrm{ha}^{-1}$, as potassium chloride) were weighed, pre-mixed, and uniformly sidedressed by hand immediately before hilling. Ammonium sulfate was used because it is the major $\mathrm{N}$ source preferred on 'Atlantic' potato by farmers and in the studies with potato crop in Brazil [23-25], and considering the low demands of 7 to $8 \mathrm{~kg} \mathrm{ha}^{-1} \mathrm{~S}$ by cultivar Atlantic [2].

Irrigation was not used and diseases and insect control followed the technical recommendations for the crop and the criteria adopted by the growers. Potato vine killing was performed using the herbicide Diquat (330 $\mathrm{g}$ a.i. ha $\left.\mathrm{h}^{-1}\right)$ at $90 \mathrm{DAP}$ and $95 \mathrm{DAP}$ for the experiments in summer-fall and spring growing season, respectively. In both experiments, the two centermost rows were machine harvested at 120 DAP. Tubers were weighed and marketable tuber (> $45 \mathrm{~mm}$ diameter) yield (MY) was separated from unmarketable tubers 
( $<45 \mathrm{~mm}$ diameter), with the aid of a scale and a classification table. From each plot, 10 randomly marketable tubers were sampled to estimate the average SG [SG = weight in air / (weight in air strength - weight in water)]. In each growing season four replicates of plots of same dimensions were randomized collected in adjacent commercial fields, in order to compare the MY in conventionally fertilized plants. In these areas, traditional fertilization criteria, with $3.0 \mathrm{Mg} \mathrm{ha}^{-1}$ of $4-14-8 \mathrm{NPK}$ and $60 \mathrm{~kg}^{-1}$ ammonium sulfate- $\mathrm{N}$ as sidedressing, were used.

\section{Calculations and statistical analysis}

In both experiments, the experimental design was a randomized complete block with a $4 \times 4$ factorial scheme and three replications. Data analysis was performed separately for each experiment because soil attributes (Table 1) and weather conditions (Figure 1) in each experiment were very different. The $\mathrm{N}$ and $\mathrm{K}$ fertilizer rates were considered fixed effects. The blocks and all of the block interactions were considered random effects. Dependent variable results were fitted to surface responses with multiple regressions according to determination coefficients and $\mathrm{P}$ values, using Sigmaplot 12.0 software.

The interaction between $\mathrm{N}$ and $\mathrm{K}$ sidedressing rates in both growing seasons was evaluated according to the equation 1 [26].

$$
\frac{M Y_{N K}}{M Y_{0}}=\frac{M Y_{N}}{M Y_{0}} \times \frac{M Y_{K}}{M Y_{0}}
$$

$$
\text { (C) } \quad(A) \quad(B)
$$

Where $M Y_{N K}=$ marketable tuber yield with optimal $\mathrm{N}$ and $\mathrm{K}$ sidedressing rates; $M Y_{0}=$ marketable tuber yield in the control treatment; $M Y_{N}=$ marketable tuber yield with only optimum $N$ sidedressing rate and $M Y_{K}$ = marketable tuber yield with only optimum $\mathrm{K}$ sidedressing rate. The $\mathrm{N} \times \mathrm{K}$ interaction with sidedress fertilization was classified as synergism, antagonist, zero-interaction or Liebig-synergism if respectively $C>A+B, C<A+B, C=A+B$ and $C>A+B$ with $C \approx A$ or $C \approx B$.

With the yields from adjacent commercial fields, where the fertilization was $180 \mathrm{~kg} \mathrm{ha}^{-1} \mathrm{~N}, 420 \mathrm{~kg} \mathrm{ha}^{-1}$ $\mathrm{P}_{2} \mathrm{O}_{5}$ and $240 \mathrm{~kg} \mathrm{ha}^{-1} \mathrm{~K}_{2} \mathrm{O}$, extrapolations were made based on the equations from the surface responses (i.e., $96 \mathrm{~kg} \mathrm{ha}^{-1} \mathrm{~N}$ and $156 \mathrm{~kg} \mathrm{ha}^{-1} \mathrm{~K}_{2} \mathrm{O}$ ). Thus, MY with similar NPK amounts and with best combinations of $\mathrm{N}$ and $\mathrm{K}$ rates sidedressing were economically compared between experiments and adjacent commercial fields. This referred to the differences between total $\mathrm{N}$ and $\mathrm{K}_{2} \mathrm{O}$ used in commercial fields and of these elements (84 kg ha ${ }^{-1}$ each) applied at planting time, in both experiments. Economic calculations were made based on the values paid, or received, by the potato farmers for the different fertilizer formulas, as of $\mathrm{R} \$ 1,360.00 \mathrm{Mg}^{-1}$ for 4-14-8 NPK, $\mathrm{R} \$ 1,800.00 \mathrm{Mg}^{-1}$ for 6-30-6 NPK, $\mathrm{R} \$ 1,365.72 \mathrm{Mg}^{-1}$ for ammonium sulphate, $R \$ 1,900.11 \mathrm{Mg}^{-1}$ for potassium chloride, and $R \$ 1,300.00 \mathrm{Mg}^{-1}$ as price of marketable tubers sold.

\section{RESULTS AND DISCUSSION}

\section{Marketable tuber yield}

The average MY was $68 \%$ lower in the summer-fall $\left(15,924 \mathrm{~kg} \mathrm{ha}^{-1}\right.$; Figure $\left.2 \mathrm{~A}\right)$ compared to the spring growing season experiment $\left(49,844 \mathrm{~kg} \mathrm{ha}^{-1}\right.$; Figure $\left.2 \mathrm{~B}\right)$. In the spring growing season, mean temperatures and rainfall volumes were $13 \%$ and $26 \%$ higher, respectively, after 40 DAP (i.e., tuberization period) than for the summer-fall experiment (Figure 1). This may explain the differences found for MY. Yorinori [3] also observed larger (48\%) total yield of 'Atlantic' potato tubers in the spring experiment $\left(35,500 \mathrm{~kg} \mathrm{ha}^{-1}\right)$ than in the summer-fall experiment $\left(24,000 \mathrm{~kg} \mathrm{ha}^{-1}\right)$, with higher demand for $\mathrm{N}$ in the spring, and higher for $\mathrm{K}$ in the summer-fall experiment, respectively. 
A)

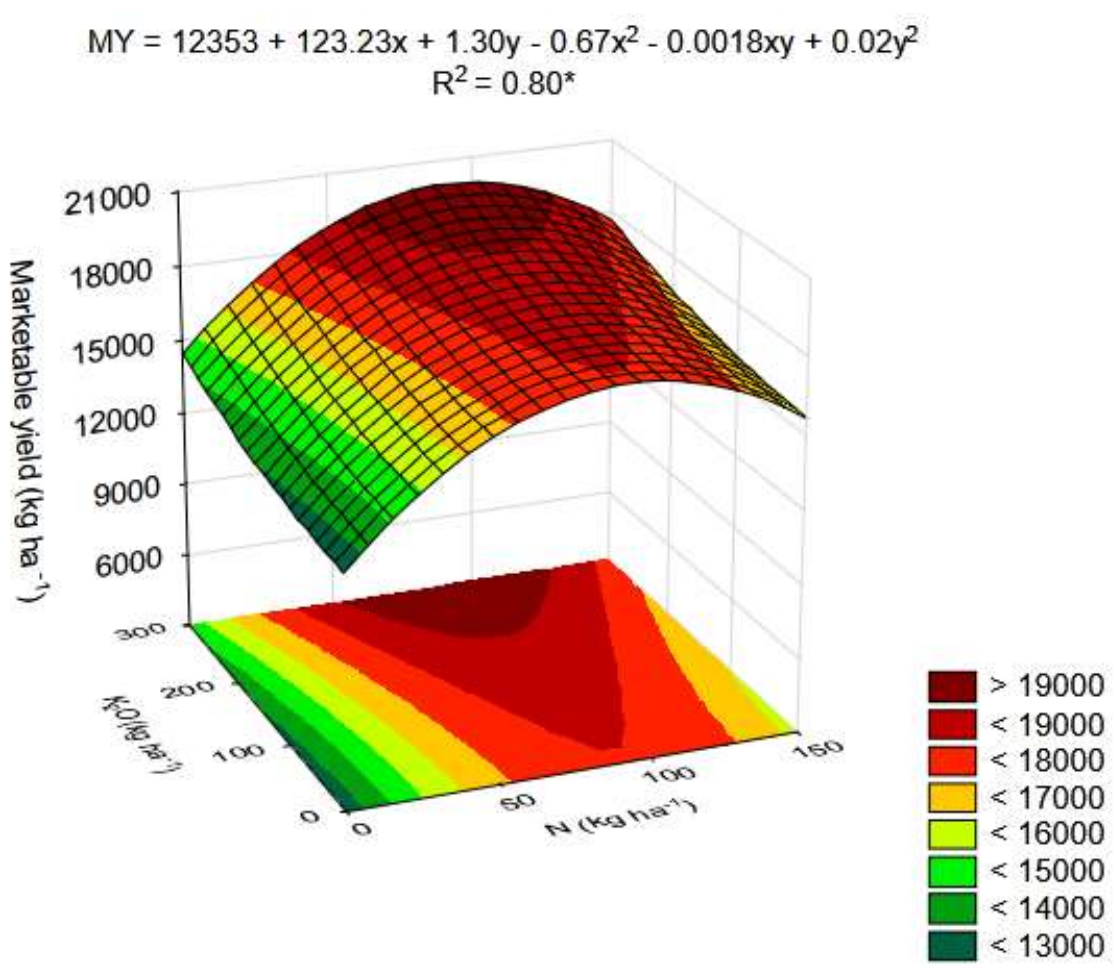

B)

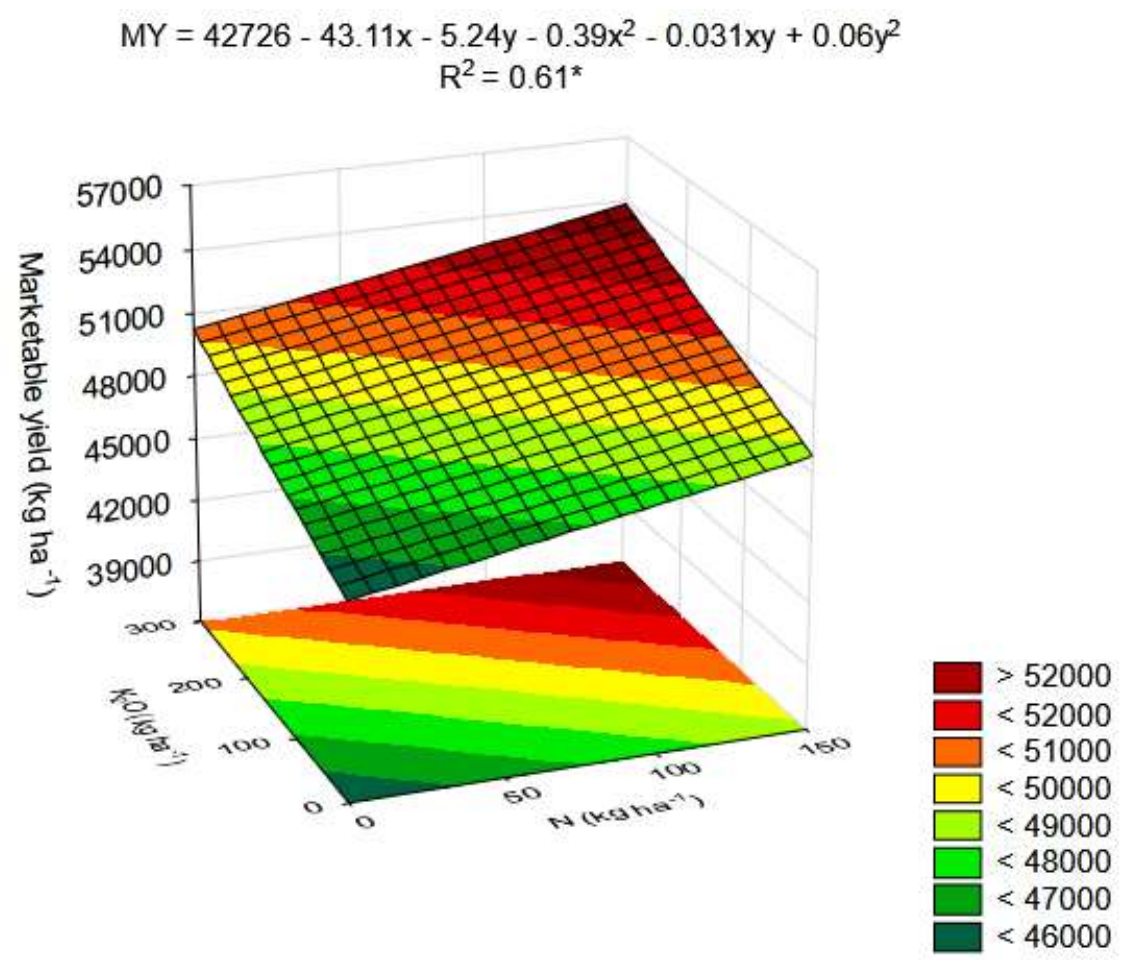

Figure 2. Marketable tuber yield (MY) of "Atlantic" potato as affected by sidedressed $N$ and $K$ fertilization rates in the summer-fall $(A)$ and spring $(B)$ growing seasons. *: significant at $5 \%$ probability.

Compared to control treatment (no sidedressed $\mathrm{N}$ or $\mathrm{K}$ application), isolated $\mathrm{N}$ sidedressing rates increased MY by $53 \%\left(6,466 \mathrm{~kg} \mathrm{ha}^{-1}\right)$ up to $91 \mathrm{~kg} \mathrm{ha}^{-1} \mathrm{~N}$ in the summer-fall experiment (Figure 2A; Table 2) and $8 \%\left(3,705 \mathrm{~kg} \mathrm{ha}^{-1}\right)$ with the highest rate $\left(150 \mathrm{~kg} \mathrm{ha}^{-1} \mathrm{~N}\right)$ in the spring experiment (Figure 2B; Table 2). According to response surfaces for summer-fall experiment, the rates from 60 to $90 \mathrm{~kg} \mathrm{ha}^{-1}$ of sidedressed $\mathrm{N}$ as ammonium sulfate, commonly used by Brazilian 'Atlantic' potato growers, resulted in increases from $47 \%$ to $53 \%$ in MY, respectively; however, no effect was observed in the spring experiment (Figure 2). The greater volume of rainfall in the summer-fall experiment, especially between 20 and 60 days after planting (Figure 1), probably enhanced the response to the $\mathrm{N}$ fertilization. On the other hand, the spring experiment, in addition 
to having less rainfall and probably less $\mathrm{N}$ leaching, it also presented a higher MY even without sideressed $\mathrm{N}$ fertilization. The sidedressed $\mathrm{N}$ rate that promoted the maximum MY was lower in the summer-fall than in the spring experiment, which may also be related to the higher temperatures and rainfall in the initial phase of potato cycle in the summer-fall growing season. Rens and coauthors [27] also did not observe increments in $\mathrm{MY}$ increasing sidedressed $\mathrm{N}$ rates at 'Atlantic' potato tuber initiation in seven experiments over three years. Studying ammonium sulfate rates at planting of 'Atlantic' potato in the summer-fall season under tropical conditions, Fontes and coauthors [24] and Fontes and coauthors [28] observed respectively maximum MY values of $33,305 \mathrm{~kg} \mathrm{ha}^{-1}\left(18 \%\right.$ increase or $\left.5,043 \mathrm{~kg} \mathrm{ha}^{-1}\right)$ with $175 \mathrm{~kg} \mathrm{ha}^{-1} \mathrm{~N}$, and $37,985 \mathrm{~kg} \mathrm{ha}$ ${ }^{1}\left(32 \%\right.$ increase or $\left.9,150 \mathrm{~kg} \mathrm{ha}^{-1}\right)$ with $205 \mathrm{~kg} \mathrm{ha}^{-1} \mathrm{~N}$. However, high $\mathrm{N}$ rates at the tuber initiation also may decrease MY and also to result in higher residual soil mineral $\mathrm{N}$ at the end of the cycle [29].

Table 2. Marketable tuber yield increases and relative tuber yields (in parenthesis) both in relation to control treatment with sidedressed $\mathrm{N}$ and/or $\mathrm{K}$ fertilization to the 'Atlantic' potato crop.

\begin{tabular}{lccc}
\hline Growing season & $\mathrm{N}$ & $\mathrm{K}$ & $\mathrm{NK}$ \\
\hline Summer-fall & $6,466 \mathrm{~kg} \mathrm{ha}^{-1}(1.53)$ & $1,959 \mathrm{~kg} \mathrm{ha}^{-1}(1.16)$ & $8,425 \mathrm{~kg} \mathrm{ha}^{-1}(1.69)$ \\
Spring & $3,705 \mathrm{~kg} \mathrm{ha}^{-1}(1.08)$ & $5,806 \mathrm{~kg} \mathrm{ha}^{-1}(1.13)$ & $9,511 \mathrm{~kg} \mathrm{ha}^{-1}(1.21)$ \\
\hline
\end{tabular}

The isolated $\mathrm{K}$ sidedressing rates increased $\mathrm{MY}$ in $16 \%\left(1,959 \mathrm{~kg} \mathrm{ha}^{-1}\right)$ and $13 \%\left(5,806 \mathrm{~kg} \mathrm{ha}^{-1}\right)$ up to the highest $\mathrm{K}$ rate applied as sidedressing $\left(300 \mathrm{~kg} \mathrm{~K}_{2} \mathrm{O} \mathrm{ha}^{-1}\right)$, respectively, in the summer-fall and spring experiments (Figures 2A and 2B; Table 2). In sandy soils, the 'Atlantic' potato did not have tuber yield increase in response to $\mathrm{KCl}$ rates at planting for four years [30]. In a clayey Oxisol with medium exchangeable $\mathrm{K}$ (summer-fall experiment) and in a sandy loam Inceptisol with high exchangeable $\mathrm{K}$ (spring experiment) (Table 1), the recommended $\mathrm{K}_{2} \mathrm{O}$ rates to the maximum MY values achieved would be 151-200 and $201-250 \mathrm{~kg}$ ha ${ }_{1}^{1}$, respectively [18]. These $\mathrm{K}$ rates at planting are on average $54 \%$ and $41 \%$ lower than the maximum rate of $384 \mathrm{~kg} \mathrm{ha}^{-1} \mathrm{~K}_{2} \mathrm{O}$ applied in both experiments (22\% at planting and $78 \%$ at sidedressing). This suggests that higher rates of split $\mathrm{K}$ fertilization at planting and sidedressing can be applied under these edaphoclimatic conditions.

In both experiments, the MY was higher with combined application of $\mathrm{N}$ and $\mathrm{K}$ at sidedressing in comparison to the isolated application of each of these nutrients (Figures 2A and 2B; Table 2). Compared to control treatment (no sidedressed N or K application), MY was increased by $69 \%\left(8,425 \mathrm{~kg} \mathrm{ha}^{-1}\right)$ with $91 \mathrm{~kg}$ ha $^{-1} \mathrm{~N}$ plus $300 \mathrm{~kg} \mathrm{ha}^{-1} \mathrm{~K}_{2} \mathrm{O}$ in the summer-fall experiment (Figure $2 \mathrm{~A}$; Table 2) and by $21 \%\left(9,511 \mathrm{~kg} \mathrm{ha}^{-1}\right)$ with $150 \mathrm{~kg} \mathrm{ha}^{-1} \mathrm{~N}$ plus $300 \mathrm{~kg} \mathrm{ha}^{-1} \mathrm{~K}_{2} \mathrm{O}$ in the spring experiment (Figure 2B; Table 2). The MY increases obtained with the combined optimal $\mathrm{N}$ and $\mathrm{K}$ rates were, respectively, $11 \%$ or $46 \%$ higher in the summer-fall experiment and $157 \%$ or $64 \%$ higher in the spring experiment, compared to the maximum increases of MY obtained with the optimal isolated $\mathrm{N}$ or $\mathrm{K}$ fertilization rates. Thus, our results confirm the hypothesis that the classic interactive effect of planting-applied $\mathrm{N}$ and $\mathrm{K}$ increasing potato tuber yield [4-8] also occurs with combined application of these nutrients as sidedressing before hilling. According to the criteria described by Rietra and coauthors [26], this interaction would be Liebig-synergistic because relative tuber yields with optimum $\mathrm{N}$ and $\mathrm{K}$ rates in both growing seasons were similar to the product between the relative tuber yields with isolated $\mathrm{N}$ or $\mathrm{K}$ fertilization (Table 2). This type of synergy occurs when adding one of the nutrients does not affect yield whereas addition of both nutrients shows an increase [26].

The interactive effect of sidedressed $\mathrm{N}$ and $\mathrm{K}$ cannot be explained by competitive uptake between $\mathrm{N}$ and $\mathrm{K}$ forms in plasma membrane level [26]. Although $\mathrm{K}^{+}$is not metabolized by plants it is crucial to protein synthesis [13,14], but $\mathrm{NH}_{4}{ }^{+}$competes for uptake and inhibits $\mathrm{K}$ translocation by high affinity transporters [13]. Tubers are the main $\mathrm{N}$ and $\mathrm{K}$ sink in potato plants, accumulating $72 \%$ of $\mathrm{N}$ and $52 \%$ of $\mathrm{K}$ taken up by the Atlantic cultivar [2]. Nitrogen $\times \mathrm{K}$ interaction synergistically increases the vegetative growth of potato plants, extending the tuber setting duration and increasing size, weight, and amounts of $\mathrm{N}$ and $\mathrm{K}$ removed by the tubers [8]. The presence of available $\mathrm{N}$ and $\mathrm{K}$ increases number and size of potato microtubers with the action of phytohormones in laboratory conditions [20] as well in the tuber size in field $[7,8]$.

\section{Planting versus sidedressing $\mathbf{N}$ and $\mathrm{K}$ rates}

Besides being significant, $\mathrm{N} \times \mathrm{K}$ interaction with sidedressing-applied rates was more profitable than with planting-applied rates (Table 3). As typically used by Brazilian potato farmers, adjacent commercial fields had received $3.0 \mathrm{Mg} \mathrm{ha}^{-1} 4-14-8 \mathrm{~N}^{-} \mathrm{P}_{2} \mathrm{O}_{5}-\mathrm{K}_{2} \mathrm{O}$ at planting plus $60 \mathrm{~kg} \mathrm{~N}^{-1}$ in sidedressing (i.e., $67 \%, 100 \%$, and $100 \%$ of total rates of 180,420 , and $240 \mathrm{~kg} \mathrm{ha}^{-1} \mathrm{~N}, \mathrm{P}_{2} \mathrm{O}_{5}$, and $\mathrm{K}_{2} \mathrm{O}$, respectively, were applied at potato planting). Having similar $\mathrm{N}-\mathrm{P}_{2} \mathrm{O}_{5}-\mathrm{K}_{2} \mathrm{O}$ total rates but with $53 \%$ of $\mathrm{N}$ and $65 \% \mathrm{~K}$ applied as sidedressing 
fertilization, there was a cost saving of $8.1 \%$ with profit increases of $R \$ 277.41$ ha $^{-1}(29.4 \%)$ in the summerfall and $\mathrm{R} \$ 235.63(7.1 \%)$ in the spring growing seasons. These results reflect the higher tuber yields with application of $\mathrm{N}$ and $\mathrm{K}$ rates in times of higher nutritional demands by potato crop, such as tuberization and tuber bulking [1-3]. In comparison with commercial fields (traditional fertilizer management), similar rates of $\mathrm{N}$ and $\mathrm{K}$ applied most as sidedressing increased MY by $20.9 \%\left(3,220 \mathrm{~kg} \mathrm{ha}^{-1}\right)$ and $5.9 \%\left(2,693 \mathrm{~kg} \mathrm{ha}^{-1}\right)$ in the summer-fall and spring growing sesons, respectively (Table 3). Optimum sidedressed $\mathrm{N}$ and $\mathrm{K}$ rates promoted MY $33.7 \%\left(5,179 \mathrm{~kg} \mathrm{ha}^{-1}\right)$ and $20.9 \%\left(9,522 \mathrm{~kg} \mathrm{ha}^{-1}\right)$ higher than the commercial fields, in the summer-fall and spring growing seasons, respectively. As a result, profits also increased by $46.0 \%$ $\left(\mathrm{R} \$ 434.78 \mathrm{ha}^{-1}\right)$ in the summer-fall and by $22.6 \%\left(\mathrm{R} \$ 754.34 \mathrm{ha}^{-1}\right)$ in the spring growing season (Table 3$)$.

Table 3. Nitrogen and potassium fertilizer rates applied at planting (PL) and in sidedressing (SD) to 'Atlantic' potato crop with traditional fertilization used in the adjacent commercial fields and in the experiments (Exp) with similar total rates or with the optimum combinations of fertilizer rates, and respective marketable yields and economic results.

\begin{tabular}{|c|c|c|c|c|c|c|c|}
\hline \multirow{2}{*}{ Fertilization management ${ }^{\mathrm{a}}$} & \multicolumn{2}{|c|}{$\mathrm{N}$} & \multicolumn{2}{|c|}{$\mathrm{K}_{2} \mathrm{O}$} & \multirow{2}{*}{$\begin{array}{c}\text { Marketable } \\
\text { yield }\end{array}$} & \multirow{2}{*}{ Costs } & \multirow{2}{*}{ Profit } \\
\hline & $\mathrm{PL}$ & SD & PL & SD & & & \\
\hline & \multicolumn{4}{|c|}{$\mathrm{kg} \mathrm{ha}^{-1}$} & $\mathrm{~kg} \mathrm{ha}^{-1}$ & \multicolumn{2}{|c|}{$\mathrm{R} \$ \mathrm{ha}^{-1}$} \\
\hline & \multicolumn{7}{|c|}{ Summer-fall } \\
\hline Traditional & 120 & 60 & 240 & 0 & 15,375 & 273.72 & 944.84 \\
\hline Similar rates (Exp) & 84 & 96 & 84 & 156 & 18,595 & 251.52 & $1,222.25$ \\
\hline Optimum rates (Exp) & 84 & 91 & 84 & $\begin{array}{r}300 \\
\text { Spr }\end{array}$ & 20,554 & 249.44 & $1,379.62$ \\
\hline Traditional & 120 & 60 & 240 & 0 & 45,543 & 273.72 & $3,335.87$ \\
\hline Similar rates (Exp) & 84 & 96 & 84 & 156 & 48,236 & 251.52 & $3,571.51$ \\
\hline Optimum rates (Exp) & 84 & 150 & 84 & 300 & 55,065 & 274.00 & $4,090.21$ \\
\hline
\end{tabular}

\section{Tuber quality}

Marketable-tuber SG responded in an opposite way to the combined application of $\mathrm{N}$ and $\mathrm{K}$ sidedressing rates in each growing season (Figure 3$)$. The SG was increased by $1.6 \%$ (0.018 units) in summer-fall experiment (Figure $3 \mathrm{~A}$ ) and decreased by $1.3 \%$ (0.014 units) in spring experiment (Figure 3B), with the application of the highest $\mathrm{N}$ and $\mathrm{K}$ sidedressing rates. These contradictory results can be attributed to the edaphoclimatic conditions of each growing season, since lower level of $\mathrm{K}^{+}$and higher levels $\mathrm{Ca}^{2+}$ and $\mathrm{Mg}^{2+}$ in the soil (Table 1) as well as greater volumes of rainfall (Figure 1) during the tuber bulking phase in the summer-fall experiment favored the positive response of marketable-tuber SG to sidedressed $\mathrm{N}$ and $\mathrm{K}$ fertilization, in contrast to the spring experiment. These results corroborate the findings that there is interaction between $\mathrm{N}$ and $\mathrm{K}$ inputs and their levels in the soil [16] and were in line with the synergistic [4] and antagonistic [16] effects reported for $\mathrm{N}$ and $\mathrm{K}$ interactions to potato crop. The application of $\mathrm{N}$ rates at planting of 'Atlantic' potato also increased, linearly or quadratically, the SG in three of five experiments in Florida-EUA, although the magnitude of those increases were lower, in the order of 0.001 to 0.003 units [27]. Despite the reported negative effects of the $\mathrm{N}$ fertilization on tuber $\mathrm{SG}$, increases of this parameter with sidedressed $\mathrm{N}$ application may be associated with the reduction in water absorption with increase of $\mathrm{NH}_{4}{ }^{+}-\mathrm{N}$ uptake by plants [16]. 
A)

$$
\begin{gathered}
S G=1.087-0.2057 x-0.0028 y-0.0017 x^{2}+0.00003 x y+0.0001 y^{2} \\
R^{2}=0.74^{\star}
\end{gathered}
$$
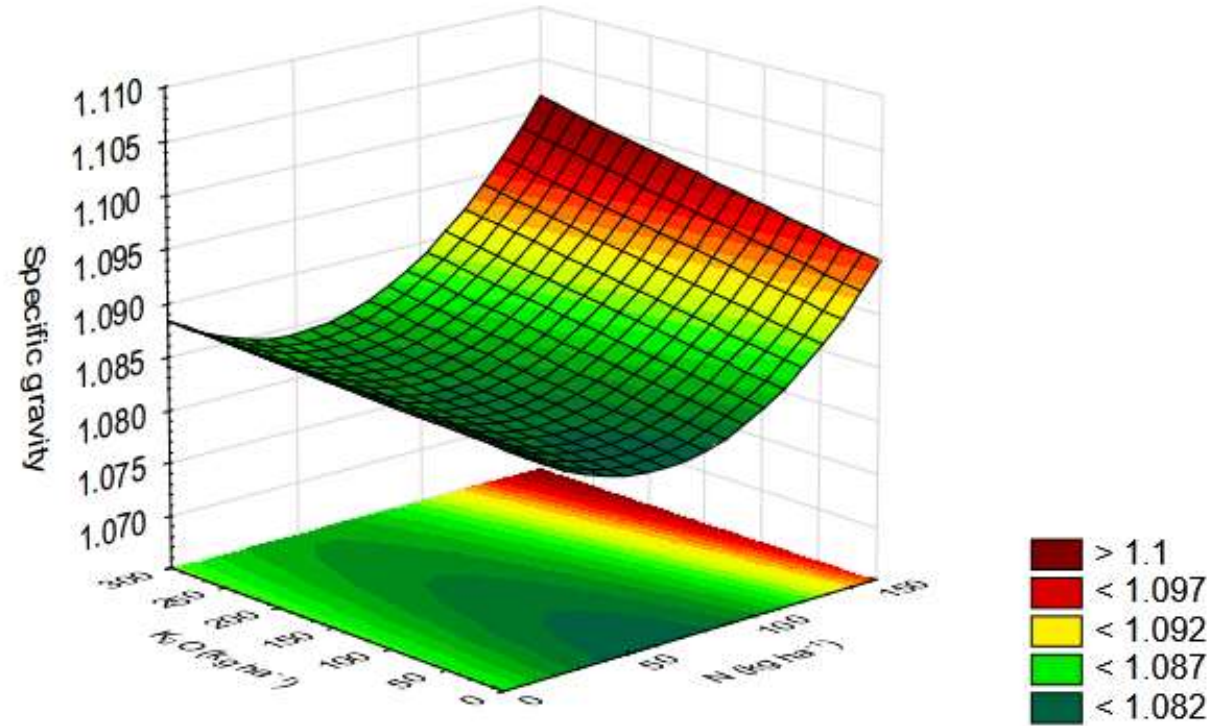

B)

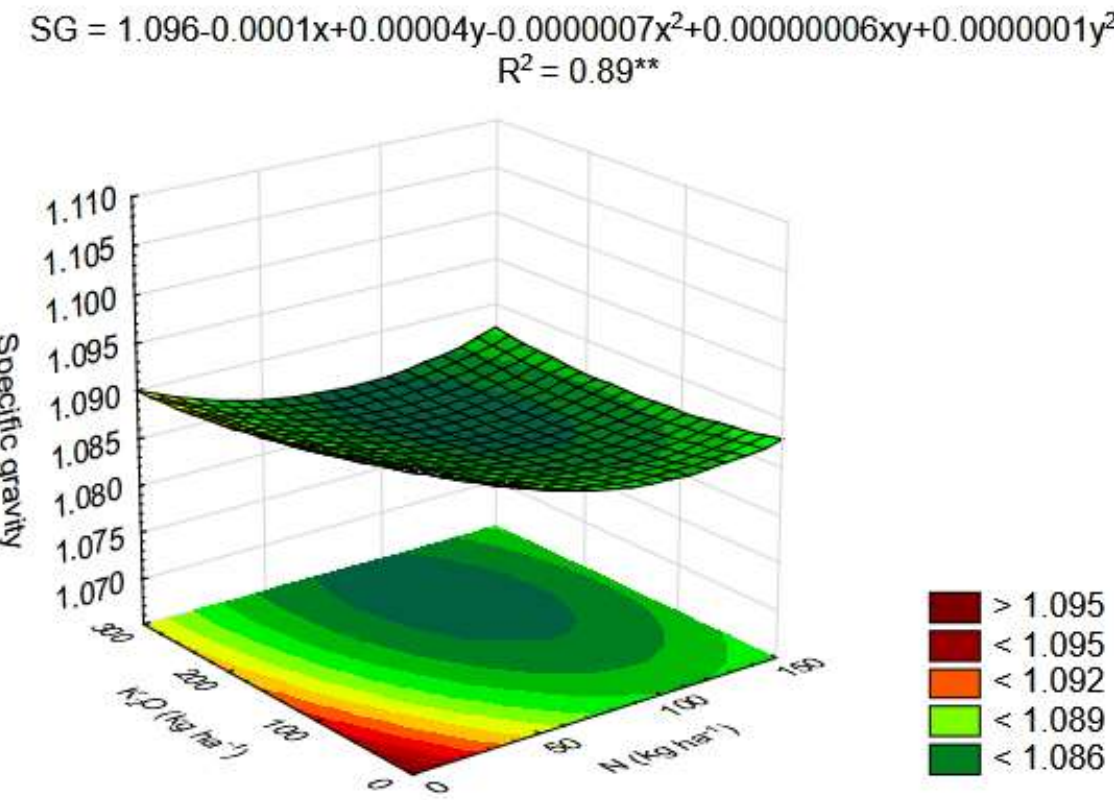

Figure 3. Specific gravity (SG) of marketable tubers of 'Atlantic' potato as affected by sidedressed $\mathrm{N}$ and $\mathrm{K}$ fertilization rates in the summer-fall $(A)$ and spring $(B)$ growing seasons. ${ }^{* *}$ and ${ }^{*}$ : significant at $1 \%$ and $5 \%$ probability.

\section{CONCLUSIONS}

Significant interaction between $\mathrm{N}$ and $\mathrm{K}$ sidedressing rates with tuber yields increase also was confirmed and classified as Liebig-synergism. Compared to the isolated $\mathrm{N}$ and $\mathrm{K}$ applications in sidedressing, joint $\mathrm{N}$ and $\mathrm{K}$ rates, respectively, increases $11 \%$ and $48 \%$ marketable tuber yields in the summer-fall experiment, and $12 \%$ and $7 \%$ in the spring experiment. Joint $\mathrm{N}$ and $\mathrm{K}$ applications as sidedressing was more profitable than their application at planting, mainly at higher $\mathrm{N}$ and $\mathrm{K}$ rates. The response of specific gravity of 'Atlantic' potato tubers to the $\mathrm{N}$ and $\mathrm{K}$ sidedressing rates was mediated by interactions between edaphoclimatic conditions and inputs of $\mathrm{N}$ and $\mathrm{K}$. The combined application of $\mathrm{N}$ and $\mathrm{K}$ sidedressing rates increased specific gravity in the summer-fall experiment, but had a negative effect in the spring experiment. 
Acknowledgments: We thank the potato grower (Dzierwa Group) who provided the areas for this investigation. We also thank the National Council for Scientific and Technological Development (CNPq) for granting an award for excellence in research to the third author.

Conflicts of Interest: The authors declare no conflict of interest.

\section{REFERENCES}

1. Westermann DT. Nutritional requirements of potatoes. Am. J. Potato Res. 2005 Jul;82:301-7. [https://eprints.nwisrl.ars.usda.gov/36/1/1186.pdf]

2. Fernandes $A M$, Soratto RP, Silva BL. Extração e exportação de nutrientes em cultivares de batata: I Macronutrientes. Rev Bras Cienc Solo. 2011 Dez; 35: 2039-2056. doi:10.1590/S0100-06832011000600020 [http://www.scielo.br/pdf/rbcs/v35n6/a20v35n6.pdf]

3. Yorinori GT. Curva de crescimento e acúmulo de nutrientes pela cultura da batata cv. 'Atlantic' [PhD tesis]; Piracicaba (SP): ESALQ, Universidade de São Paulo. Brasil; 2003. [https://teses.usp.br/teses/disponiveis/11/11140/tde-20052003-141438/publico/glaucia.PDF]

4. Westermann DT, Tindall TA, James, DW, Hurst, RL. Nitrogen and potassium fertilization of potatoes: yield and specific gravity. Am. Potato J, 1994 Jul; 71: 417-431. [https://link.springer.com/article/10.1007/BF02849097]

5. Kavvadias V, Paschalidis C, Akrivos G, Petropoulos D. Nitrogen and potassium fertilization responses of potato (Solanum tuberosum) cv. Spunta. Commun Soil Sci Plan Anal. 2012 Jan; 43: 176-189. doi: 10.1080/00103624.2012.634711. doi:

$10.1080 / 00103624.2012 .634711$

[https://link.springer.com/article/10.1007/BF02849097].

6. Kumar P, Sandey SK, Singh SV, Kumar D, Singh B, Singh S, Rawal S, Menna RL. Influence of N and K rates on yield and quality of chipping variety Kufri Chipsona-3. Potato J 2012 Jul; 39: 191-196. [https://www.researchgate.net/publication/286407029_Influence_of_N_and_K_rates_on_yield_and_quality_of_ch ipping_variety_Kufri_Chipsona-3]

7. Singh SK, Lal SS. Effect of potassium nutrition on potato yield, quality and nutrient use efficiency under varied levels of nitrogen application. Potato J, 2012 Jul; 39(2): 155-165. [https://www.researchgate.net/publication/286986053_Effect_of_potassium_nutrition_on_potato_yield_quality_an d_nutrient_use_efficiency_under_varied_levels_of_nitrogen_application]

8. Hamdi W, Rihab B, Quertatani S, Gharbi A. Effect of nitrogen and potassium levels on the potatoes growth in the Chott Mariem region of Tunisia. Aust J Exp Agric 2018 Nov; 28: 1-9. doi: 10.9734/JEAI/2018/20206 [http://www.journaljeai.com/index.php/JEAl/article/view/27082]

9. Kanzikwera CR, Tenywa JS, Osiru DSO, Adipala E, Bhagsari AS. Interactive effect of nitrogen and potassium on dry matter and nutrient partition in true potato seed mother plants. Afr Crop Sci J, 2001 Jan; 9(1): 127-146. doi: 10.4314/acsj.v9i1.27631[https://www.researchgate.net/publication/27791843_Interactive_Effect_of_Nitrogen_and _Potassium_on_Dry_Matter_and_Nutrient_Partition_in_True_Potato_Seed_Mother_Plants]

10. Araújo TH, Pádua JG, Spoto MHF, Ortiz VDG, Margossian PL, Dias CTS, Melo PCT. Productivity and quality of potato cultivars for processing as shoestrings and chips. Hort Bras. 2016 Oct/Dec; 34: 554-560. doi: 10.1590/S0102-053620160415. 05362016000400554].

11. Gerendás J, Heuser F, Sattelmacher B. Influence of nitrogen and potassium supply on contents of acrylamide precursors in potato tubers and on acrylamide accumulation in French fries. J Plant Nutr. 2007 Sep; 30, 14991516. [https://www.tandfonline.com/doi/abs/10.1080/01904160701555846]

12. Cogo CM, Andriolo JL, Bisognin DA, Godoi RD, Bortolotto OC, Luz GL. Nitrogen-potassium relationship for diagnosis of plant nutritional status and fertilization of the potato crop. Pesq Agropec Bras. 2006 Dec; 41(12): 17811786. doi: 10.1590/S0100-204X2006001200013 [http://www.scielo.br/scielo.php?pid=S0100204X2006001200013\&script=sci_abstract]

13. Zhang F, Niu JF, Zhang WF, Chen XP, Li CJ, Yuan LX, Xie JC. Potassium nutrition of crops under varied regimes of nitrogen supply. Plant Soil. 2010 Mar; 335: 21-34. doi:10.1007/s11104-010-0323-4 [https://link.springer.com/article/10.1007/s11104-010-0323-4]

14. Coskun D, Britto DT, Kronzucker HK. The nitrogen-potassium intersection: membranes, metabolism, and mechanism. Plant Cell Environ. 2016 Jan; 40: 2029-2041. doi: 10.1111/pce.12671 [https://www.ncbi.nlm.nih.gov/pubmed/26524711]

15. James DW, Hurst RL, Westermann DT, Tindall TA. Nitrogen and potassium fertilization of potato: Evaluating nutrient element interactions in petioles with response surfaces. Am Potato J. 1994 Apr; 71, 249-265. [https://link.springer.com/article/10.1007/BF02849290] 
16. Laboski CAM, Kelling KA. Influence of fertilizer management and soil fertility on tuber specific gravity: A review. Am. J. Potato Res. 2007 Aug; 84,283-290. [https://link.springer.com/article/10.1007/BFO2986240]

17. Lorenzi JO, Monteiro DA, Miranda Filho HS, van Raij B. Raízes e tubérculos, pp. 221-9. In: van Raij B., Cantarella, H., Quaggio, J.A., Furlani, A.M.C. (eds.) Recomendações de adubação e calagem para o Estado de São Paulo, 2nd ed. Boletim Técnico 100. Inst. Agron. Campinas, Campinas, 1997. pp.285.

18. NEPAR-SBCS - Núcleo Estadual Paraná-Sociedade Brasileira de Ciência do Solo. Manual de Adubação e Calagem para o Estado do Paraná. - SBCS/NEPAR, Curitiba. 2017. p. 482.

19. Kawakami J. Redução da adubação e doses e parcelamento de nitrogênio no crescimento e produtividade de batata. Hort Bras 2015 Jun; 33(2): 168-173. doi: 10.1590/S0102-053620150000200006 [http://www.scielo.br/scielo.php?script=sci_arttext\&pid=S0102-05362015000200006]

20. Zakaria M, Hossain MM, Khaleque M, Hossain T, Sultana N. Effect of nitrogen and potassium on in vitro tuberization of potato. Plant Tissue Cult Biotechnol, 2007 Jun; 17(1): 79-85. doi:10.3329/ptcb.v17i1.1124 [https://www.researchgate.net/publication/238735685_Effect_of_Nitrogen_and_Potassium_on_In_vitro_Tuberizat ion_of_Potato]

21. Pavan MA, Bloch MF, Zempulski HC, Miyazawa M, Zocoler DC. Manual de análise química do solo e controle de qualidade (Circular, 76). Instituto Agronômico do Paraná, Londrina. 1992. p. 38.

22. Empresa Brasileira de Pesquisa Agropecuária - EMBRAPA. Manual de métodos de análise do solo. - Rio de Janeiro: Embrapa Solos. 1997. p. 212.

23. Barcelos DM, Garcia A, Maciel Junior VA. Análise de crescimento da cultura da batata submetida ao parcelamento da adubaçã nitrogenada em cobertura, em um Latossolo Vermelho-Amarelo. Ciênc Agrotec, 2007 Jan/Fev; 31(1):21-7. doi:10.1590/S1413-70542007000100003. [http://www.scielo.br/pdf/cagro/v31n1/v31n1a03]

24. Fontes $\mathrm{PCR}$, Braun $\mathrm{H}$, Busato $\mathrm{C}$, Cecon $\mathrm{PR}$. Economic optimum nitrogen fertilization rates and nitrogen fertilization rate effects on tuber characteristics of potato cultivars. Potato Res, 2010 Sep; 53: 167-179. doi: 10.1007/s11540010-9160-3. [https://link.springer.com/article/10.1007/s11540-010-9160-3]

25. Silva GO, Pereira AS, Suinaga FA, Ponijaleki R. Adubação nitrogenada no rendimento da cultivar de batata BRS Ana. Hort Bras. 2014 Jan/Mar; 32: 107-10. doi: 10.1590/S0102-05362014000100018 [http://www.scielo.br/scielo.php?script=sci_arttext\&pid=S0102-05362014000100107]

26. Rietra RPJJ, Heinen M, Dimkpa CO, Bindraban PS. Effects of nutrient antagonism and synergism on yield and fertilizer use efficiency. Commun Soil Sci Plan Anal, 2017 Dez. 48 (16), 1895-1920. doi: 10.1080/00103624.2017.1407429 [https://www.tandfonline.com/doi/full/10.1080/00103624.2017.1407429]

27. Rens LR, Zotarelli L, Cantliffe DJ, Stoffella PJ, Gergela D, Fourman D. Biomass accumulation, marketable yield, and quality of Atlantic potato in response to nitrogen. Agronomy J, 2015 May; 107(3), 931-942. doi: 10.2134/agronj14.0408

[https://www.researchgate.net/publication/276508404_Biomass_Accumulation_Marketable_Yield_and_Quality_of Atlantic_Potato_in_Response_to_Nitrogen].

28. Fontes P.C.R., Braun, H., Silva, M.C.C., Coelho, F.S., Cecon, P.R., Partelli, F.L. Tuber yield prognosis model and agronomic nitrogen use efficiency of potato cultivars. Australian Journal of Crop Science, 2016 Jul; 10(7), 933-939. doi:10.21475/ajcs.2016.10.07.p7404 [http://www.cropj.com/fontes_10_7_2016_933_939.pdf].

29. Rens LR, Zotarelli L, Cantliffe DJ, Stoffella PJ, Gergela D, Burhans D. Commercial evaluation of seasonal distribution of nitrogen-fertilizer for chipping potato. Potato Res, 2016 Mar; 59: 1-20. doi: 10.1007/s11540-0159304-6

[https://www.researchgate.net/publication/302437245_Commercial_Evaluation_of_Seasonal_Distribution_of_Nitr ogen_Fertilizer_for_Potato].

30. Panique E, Kelling KA, Schulte EE, Hero DE, Stevenson WR, James RV. Potassium rate and source effects on potato yield, quality, and disease interaction. Am Potato J, 1997 Nov; 74, 379-98. [https://link.springer.com/article/10.1007/BF02852777]

2020 by the authors. Submitted for possible open access publication under the terms and conditions of the Creative Commons Attribution (CC BY NC) license (https://creativecommons.org/licenses/by-nc/4.0/). 